\title{
Analisis Kemampuan Pemahaman Konsep Matematis Peserta Didik Ditinjau Dari Adversity Quotient
}

\author{
Isnaini Handayani ${ }^{*}$, Afifah Fitria Ramadhani ${ }^{2}$ \\ 'Pendidikan Matematika, Universitas Muhammadiyah Prof. Dr. Hamka, Jakarta, Indonesia; \\ *isnaini_handayani@uhamka.ac.id \\ ${ }^{2}$ Pendidikan Matematika, Universitas Muhammadiyah Prof. Dr. Hamka, Jakarta, Indonesia; \\ afifah.fr98@gmail.com
}

\begin{abstract}
Abstrak. Penelitian ini bertujuan untuk menganalisis kemampuan pemahaman konsep peserta didik ditinjau dari adversity quotient. Adapun indikator pemahaman konsep matematis dalam penelitian ini antara lain (1) menyatakan ulang sebuah konsep, (2) mengklasifikasikan objek tertentu sesuai sifatnya, (3) memberikan contoh dan bukan contoh, (4) menyajikan konsep dalam berbagai bentuk representasi matematika, (5) menggunakan dan memanfaatkan prosedur atau operasi tertentu, (6) mengaplikasikan konsep atau algoritma dalam pemecahan masalah dan (7) mengembangkan syarat perlu atau syarat cukup dari suatu konsep. Adapun tiga tipe adversity quotient dalam penelitian ini yaitu quitter, camper, dan climber. Penelitian ini merupakan kualitatif deskriptif. Subjek dalam penelitian ini berjumlah 106 peserta didik kelas XI IPA SMAN 64 Jakarta. Instrumen yang digunakan berupa tes kemampuan pemahaman konsep dan non tes berupa angket adversity quotient. Data dianalisis dengan cara mereduksi data, penyajian data dan penarikan kesimpulan. Berdasarkan hasil penelitian, terdapat 2 peserta didik dengan AQ quitter, 60 peserta didik dengan AQ camper, dan 44 peserta didik dengan AQ climber. Hasil penelitian menunjukkan bahwa kemampuan pemahaman konsep matematika tergolong sedang dan tipe adversity quotient peserta didik tergolong tipe camper.
\end{abstract}

Kata Kunci: adversity quotient, kemampuan, pemahaman konsep matematis

Abstract. This study aims to analyze students' mathematical conceptual understanding ability based on their adversity quotient. The indicators of mathematical conceptual understanding in this study are (1) to restate a concept, (2) classifying objects by their properties, (3) giving an examples and counter examples, (4) presenting concepts into various mathematical representation, (5) to use and choose the procedure properly, (6) applying a concept or algorithm in problem solving and (7) to develop the sufficient requirements of a concept. There are three types of adversity quotients in this study are quitter, camper, and climber. This is a descriptive qualitative research. The Subjects in this study were 106 people of natural science major, in second grade of high school in Jakarta. The instrument used was the test of mathematical conseptual understanding ability and adversity quotient questionaire. Data were analyzed by reducing data, presenting the data and making the conclusions. Based on the study, there are two students with quitter types, 60 students with camper types, and 44 students with climber types. This Research indicates that 
the mathematical conceptual understanding ability is moderate category and the type of students' adversity quotient is classified as camper.

Keywords: adversity quotient, ability, mathematical conceptual understanding

\section{Pendahuluan}

Matematika dipelajari dalam rangka untuk mengembangkan beberapa aspek kemampuan, diantaranya adalah pemahaman konsep, pemecahan masalah, penalaran, dan komunikasi matematis Indriani et al., (2019). Untuk mengembangkan kemampuan-kemampuan tersebut, diperlukan suatu proses pembelajaran secara terus menerus dan simultan. Dalam pembelajaran matematika terdapat dua tipe belajar yaitu rote learning dan meaningful learning Mulyono \& Hapizah (2018). Meaningful learning lebih menekankan kepada pemahaman konsep yang dipelajari. Apabila peserta didik belum mampu memahami konsep matematika, maka tujuan yang diharapkan tidak mungkin terjadi dan peserta didik akan mengalami kesulitan dalam proses pembelajaran. Agar mudah dipahami, pemahaman konsep memerlukan keterkaitan antar konsep dan mengaplikasikan konsep secara luwes, akurat, efisien, dan tepat dalam memecahkan masalah Maharani et al., (2013). Selain itu memahami konsep bukan hanya sekedar tahu atau mengingat konsep yang dipelajari namun mampu mengungkapkan kembali dalam bentuk yang mudah dimengerti Rahmawati \& Kusuma (2019). Pentingnya memahami konsep memungkinkan peserta didik mampu memecahkan masalah matematika dengan baik Fajar et al., (2018). Selain itu, Kurniawan (Gusniwati, 2015) mengungkapkan bahwa menguasai konsep merupakan modal utama dalam mengerjakan soal. Karena memahami pemahaman matematis merupakan tujuan yang penting dalam pembelajaran bukan hanya sekedar hafalan melainkan melebihi itu Maharani et al., (2013).

Dalam Pranata (2016), berdasarkan hasil survei TIMSS tentang prestasi matematika, menunjukkan bahwa masih banyak siswa yang mengalami kesulitan dalam memahami konsep - konsep matematika. Pemahaman konsep adalah suatu kemampuan yang dimiliki seseorang dalam memahami, memaknai, mengidentifikasi, dan menjelaskan kembali konsep atau definisi serta kemampuan seseorang dalam memilih prosedur secara efisien dan tepat Pranata (2016). Pemahaman yang dimaksud juga berhubungan dengan bagaimana peserta didik mampu bersikap, berpikir, dan bertindak dalam memahami definisi, ciri khusus, hakikat, dan isi dari matematika dan mampu memilih prosedur secara efisien dan tepat Gusniwati (2015). 
Untuk mengukur pemahaman konsep matematis terdapat beberapa indikator atau tolok ukur yaitu : (1) menyatakan ulang sebuah konsep; (2) mengklasifikasikan objek tertentu dengan sifatnya; (3) memberi contoh dan bukan contoh; (4) menyajikan konsep dalam berbagai bentuk representasi matematis; (5) mengembangkan syarat perlu atau syarat cukup dari konsep; (6) menggunakan dan memanfaatkan prosedur atau operasi tertentu; dan (7) mengaplikasikan konsep atau algoritma dalam pemecahan masalah Budiarti et al., (2019). Selain itu, Suraji et al., (2018) menggabungkan beberapa indikator pemahaman konsep matematis menjadi tiga item indikator yaitu : (1) menyatakan ulang sebuah konsep dan mengklasifikasikan objek sesuai dengan konsepnya; (2) menyajikan konsep dalam berbagai bentuk representasi matematis; (3) menggunakan, memilih prosedur atau operasi tertentu, memanfaatkan serta mengaplikasikan konsep.

Berdasarkan hasil observasi dan informasi dari guru mata pelajaran matematika siswa SMA di Imogiri Saputri \& Sujadi (2014) menemukan beberapa masalah diantaranya: (1) siswa kurang aktif dan cenderung kurang dalam memahami konsep, (2) model pembelajaran yang kurang bervariasi, dan (3) malas bertanya ketika mengalami kesulitan, penelitian lain mengatakan bahwa kurangnya pemahaman konsep matematis peserta didik berpengaruh terhadap pola belajar peserta didik Gusniwati (2015). Menurut Triwibowo et al., (2018), berdasarkan hasil wawancara dengan guru pelajaran matematika, pemahaman konsep matematis siswa SMA di Semarang masih rendah, hal ini dikarenakan peserta didik (1) kesulitan menyajikan konsep dengan berbagai bentuk representasi dan memahami soal cerita, (2) belum dapat mengaplikasi konsep secara runtut, dan (3) masih kesulitan dalam menggunakan, memanfaatkan, dan memilih prosedur operasi tertentu. Faktanya, pemahaman konsep yang dimiliki siswa belum pada tingkat yang memuaskan. Adapun kurangnya pemahaman konsep peserta didik dalam pemecahan masalah disebabkan oleh metode belajar maupun soal - soal yang diberikan guru pada saat proses belajar mengajar. Guru harus mampu memilih metode pembelajaran dan soal-soal yang tidak hanya untuk mentransfer materi, tetapi juga mampu membangun pemahaman konsep matematis peserta didik. Peserta didik dikatakan memahami suatu konsep apabila peserta didik mampu mengemukakan kembali ilmu yang diperolehnya baik dalam ucapan maupun tulisan kepada orang lain sehingga orang lain tersebut benar - benar mengerti yang disampaikan Suraji et al., (2018). Oleh karena itu, untuk memahamkan suatu konsep kepada peserta didik tidak dapat diberikan dengan paksaan, tetapi dengan metode belajar yang tepat dan efisien.

Copyright $@ 2020$

\section{Buana Matematika :}

Jurnal Ilmiah Matematika dan Pendidikan Matematika 
Dalam proses belajar, setiap peserta didik tentu mengalami kesulitan dalam belajar ataupun memahami materi yang diajarkan. Setiap peserta didik tentu memiliki cara tersendiri dalam mengatasi kendala belajar yang dialaminya. Ada peserta didik yang menyikapinya secara positif dan adapula yang negatif. Sikap yang dimiliki oleh seseorang untuk mengatasi kesulitan termasuk dalam faktor internal, salah satunya adalah adalah Adversity Quotient (AQ) Phoolka \& Kaur (2012). AQ adalah bentuk kecerdasan selain SQ, IQ, dan EQ yang bertujuan untuk bertahan dalam situasi yang sulit dalam pembelajaran. AQ adalah kecerdasan dalam mengatasi kesulitan Stoltz \& (Penerjemah) (2018a). AQ digunakan untuk menilai sejauh mana seseorang ketika menghadapi masalah sulit.

AQ terbagi dalam tiga kategori yaitu quitters (orang-orang yang mudah menyerah), campers (orang-orang yang mudah puas), dan climbers (orangorang yang terus berusaha) Stoltz \& (Penerjemah) (2018b). Setiap kategori memiliki cara tersendiri dalam mengatasi kesulitan. Pada tipe climbers, mereka akan tetap bertahan dan tetap terus berusaha sehingga mampu memunculkan ide untuk mengatasi kesulitan. Mereka percaya bahwa apa yang dilakukannya akan mendatangkan hasil. Peserta didik dengan kategori climbers akan mencapai tingkat paling tinggi diantara ketiga kategori AQ lainnya, kemudian disusul dengan kategori campers dan quitters.

Terdapat empat dimensi dalam AQ yakni control (kendali), origin and ownership (asal usul dan pengakuan), reach (jangkauan) dan endurance (daya tahan). Control diperlukan ketika peserta didik merasakan adanya kesulitan, origin and ownership yaitu asal usul adanya kesulitan dan pengakuan terhadap terjadinya kesulitan, reach adalah sejauh mana kesulitan dianggap mampu menjangkau ke bagian dari kehidupan dan endurance tentang anggapan peserta didik berapa lama kesulitan itu berlangsung Yanti \& Syazali (2016).

Berdasarkan uraian diatas, penulis tertarik untuk menganalisis tentang kemampuan pemahaman konsep matematika ditinjau dari adversity quotient. Tujuan penelitian ini untuk mendeskripsikan dan menganalisis kemampuan pemahaman konsep matematis dari masing - masing kategori adversity quotient.

\section{Metode}

Penelitian ini merupakan penelitian deskriptif kualitatif. Subjek penelitian ini adalah seluruh kelas XI IPA SMAN 64 Jakarta sebanyak 106 peserta didik. Teknik pengumpulan data menggunakan instrumen tes dan non tes.

Copyright $@ 2020$

Buana Matematika :

Jurnal Ilmiah Matematika dan Pendidikan Matematika 
Instrumen tes digunakan untuk mengukur pemahaman konsep matematika peserta didik pada materi barisan dan deret. Sedangkan instrumen non tes untuk menentukan kategori adversity quotient, menggunakan angket yang diadaptasi dari (Hidayat, Herdiman, Aripin, Yuliani, \& Maya, 2018). Terdapat lima alternatif pilihan jawaban yaitu terdiri dari SS (Sangat Setuju), S (Setuju), N (Netral), TS (Tidak Setuju), dan STS (Sangat Tidak Setuju). Terdiri dari dua kelompok yaitu kelompok yang mendukung sikap positif (favourable) dan kelompok yang mendukung sikap negatif (unfavourable). Adapun pedoman penskoran kemampuan pemahaman konsep matematika berdasarkan indikatornya, disajikan pada tabel 1 berikut:

Tabel 1. Pedoman Penskoran Kemampuan Pemahaman Konsep Matematika

\begin{tabular}{|c|c|c|}
\hline $\begin{array}{l}\text { Indikator pemahaman } \\
\text { konsep }\end{array}$ & Keterangan & Skor \\
\hline $\begin{array}{l}\text { Menyatakan } \\
\text { sebuah konsep }\end{array}$ & $\begin{array}{l}\text { Jawaban kosong } \\
\text { Tidak mampu menyatakan ulang konsep } \\
\text { Mampu menyatakan ulang konsep tetapi masih banyak } \\
\text { kesalahan } \\
\text { Mampu menyatakan ulang konsep tetapi belum tepat } \\
\text { Mampu menyatakan ulang konsep dengan tepat }\end{array}$ & $\begin{array}{l}0 \\
1 \\
2\end{array}$ \\
\hline $\begin{array}{l}\text { Memberikan contoh dan } \\
\text { bukan contoh dari suatu } \\
\text { konsep }\end{array}$ & $\begin{array}{l}\text { Jawaban kosong } \\
\text { Tidak mampu memberi contoh dan bukan contoh } \\
\text { Mampu memberikan contoh dan bukan contoh tetapi masih } \\
\text { banyak kesalahan } \\
\text { Mampu memberikan contoh dan bukan contoh tetapi belum } \\
\text { tepat } \\
\text { Mampu memberikan contoh dan bukan contoh dengan tepat }\end{array}$ & $\begin{array}{l}0 \\
1 \\
2\end{array}$ \\
\hline $\begin{array}{l}\text { Mengklasifikasi objek } \\
\text { menurut sifat-sifat } \\
\text { tertentu sesuai dengan } \\
\text { konsepnya }\end{array}$ & $\begin{array}{l}\text { Jawaban kosong } \\
\text { Tidak mampu mengklasifikasikan objek sesuai dengan } \\
\text { konsepnya } \\
\text { Mampu menyebutkan sifat-sifat sesuai dengan konsepnya } \\
\text { tetapi masih banyak kesalahan } \\
\text { Mampu menyebutkan sifat-sifat sesuai dengan konsepnya } \\
\text { tetapi belum tepat } \\
\text { Mampu menyebutkan sifat-sifat sesuai dengan konsepnya } \\
\text { dengan tepat }\end{array}$ & $\begin{array}{l}0 \\
1\end{array}$ \\
\hline $\begin{array}{lr}\text { Menyajikan } & \text { konsep } \\
\text { dalam } & \text { bentuk } \\
\text { representasi matematis }\end{array}$ & $\begin{array}{l}\text { Jawaban kosong } \\
\text { Mampu menyajikan sebuah konsep dalam bentuk representasi } \\
\text { matematika (gambar) tetapi belum tepat dan tidak } \\
\text { menggunakan busur } \\
\text { Mampu menyajikan sebuah konsep dalam bentuk representasi } \\
\text { matematika (gambar) tetapi belum tepat } \\
\text { Mampu menyajikan sebuah konsep dalam bentuk representasi } \\
\text { matematika (gambar) tetapi tidak menggunakan busur } \\
\text { Mampu menyajikan sebuah konsep dalam bentuk representasi } \\
\text { matematika (gambar) dengan tepat }\end{array}$ & $\begin{array}{l}0 \\
1\end{array}$ \\
\hline
\end{tabular}


Vol. 10 No. 1 (2020)

\begin{tabular}{ccc}
\hline $\begin{array}{c}\text { Indikator pemahaman } \\
\text { konsep }\end{array}$ & Keterangan & Skor \\
\hline
\end{tabular}

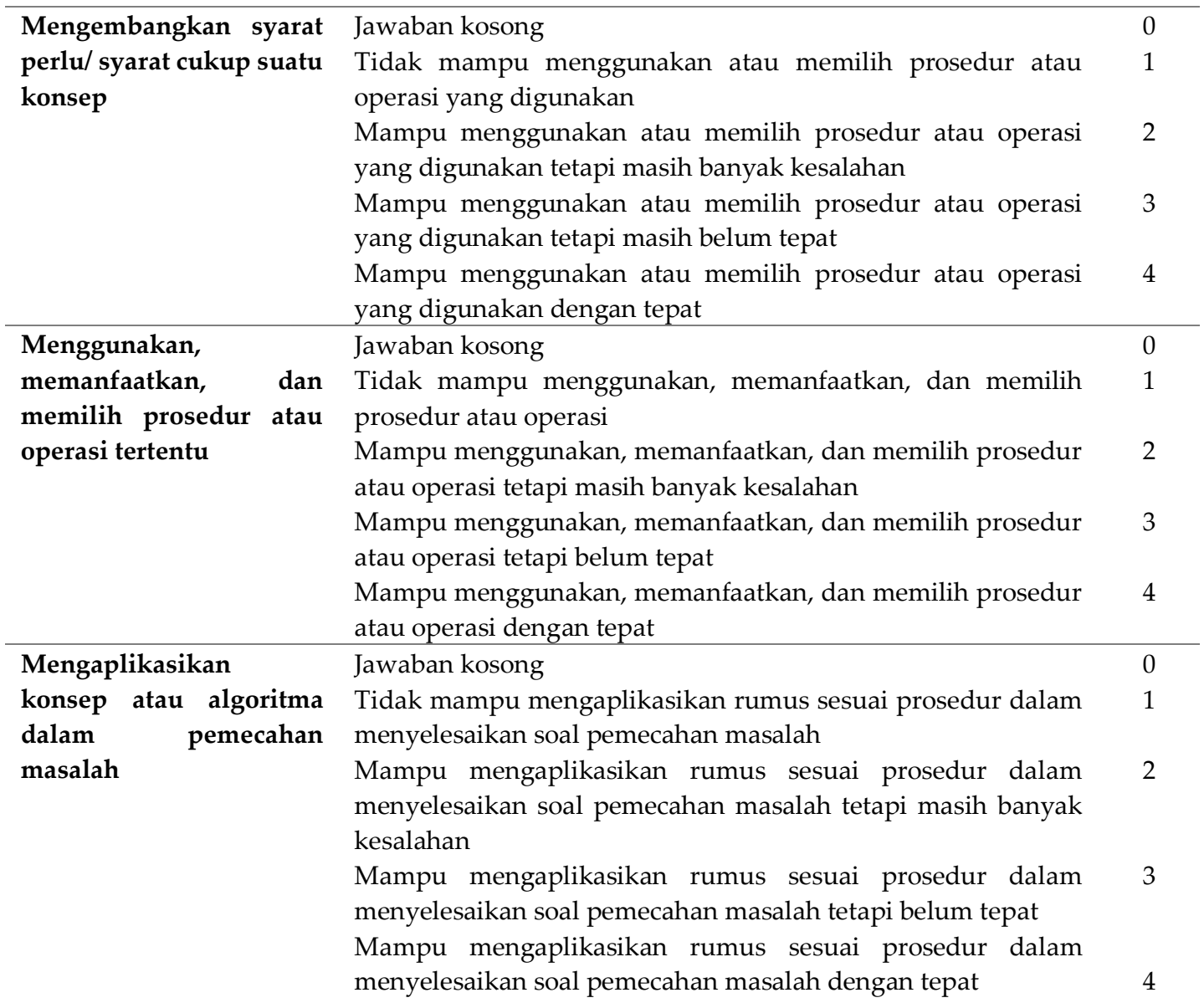

Di adaptasi dari Mawaddah \& Maryanti (2016)

Data yang didapatkan dari hasil tes kemampuan pemahaman konsep matematika diolah dengan memberikan skor jawaban berdasarkan pedoman skor yang digunakan. Selanjutnya dibuat tabel skor kemampuan pemahaman konsep matematika dalam bentuk excel. Hasil skor angket adversity quotient dan skor kemampuan pemahaman konsep matematika dianalisis menggunakan model Rasch dan dibantu oleh Winstep yang di kembangkan oleh Linacre (2006). Data ditabulasi dalam Ms. Excel kemudian di konversi dan dianalisis dengan bantuan Winstep 4.3.4 dalam sistem operasi windows 10 .

\section{Hasil dan Pembahasan}

Hasil penelitian dianalisis dengan model Rasch dibantu oleh software Winstep. Dari 108 responden, terdapat 2 responden yang tidak hadir. Oleh karena itu data yang diolah berjumlah 106 responden.

Copyright $@ 2020$

\section{Buana Matematika :}

Jurnal Ilmiah Matematika dan Pendidikan Matematika 
Pada analisis data dengan menggunakan model Rasch, pengukuran terhadap validitas isi dan validitas konstruk mampu dievaluasi secara lebih tepat selain itu peneliti mampu melihat responden yang memiliki jawaban yang paling tidak konsisten. Gambar 1 merepresentasikan interaksi antara responden dan item adversity quotient.

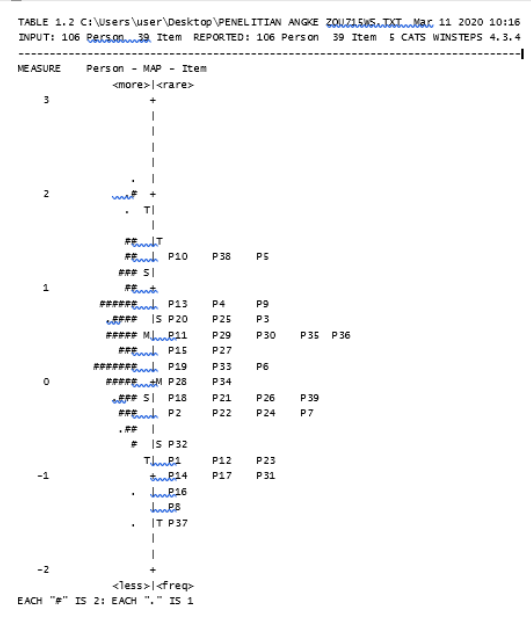

Gambar 1. Interaksi antara responden dan item adversity quotient

Dari gambar 1 terlihat bahwa item nomor 8, 16, dan 37 merupakan item yang paling mudah disetujui seluruh responden, yaitu "Ketika memiliki kesulitan dalam menyelesaikan soal matematika, saya yakin mampu mengatasinya jika mau berusaha"; "Jika saya mampu memahami konsep matematika, maka matematika adalah sesuatu yang mudah bagi saya" dan "Jika saya rajin berlatih maka saya lancar menyelesaikan soal". Hal ini mungkin dikarenakan item tersebut merupakan pernyataan yang umum sehingga responden cenderung untuk menyetujuinya. Berdasarkan mistar logit diperoleh informasi bahwa 2 responden berada pada level rendah (1,89\%) atau tipe quitter, 85 orang responden berada pada level sedang (80,19\%) atau tipe camper, dan 19 orang responden berada pada level tinggi $(17,92 \%)$ atau tipe climber. Oleh karena itulah dapat disimpulkan bahwa adversity quotient sebagian besar responden berada pada level sedang atau tipe camper. 


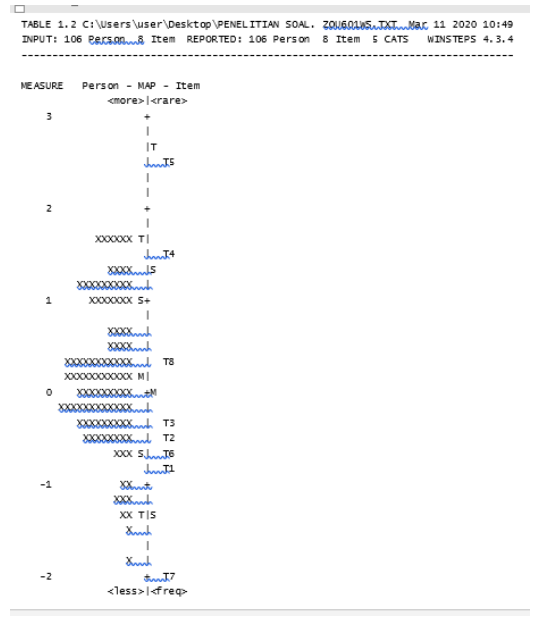

Gambar 2. Interaksi antara responden dan tes kemampuan pemahaman konsep matematis

Dari gambar 2 terlihat bahwa soal nomor 7 merupakan soal yang paling mudah dikerjakan seluruh responden, disajikan pada gambar 3 berikut:

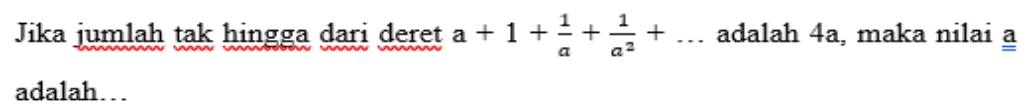

Gambar 3. Soal nomor 7

Hal ini dikarenakan soal tersebut merupakan soal yang umum sehingga responden cenderung untuk menyetujuinya. Berdasarkan mistar logit diperoleh informasi bahwa 4 responden berada pada level rendah (3,78\%), 83 orang responden berada pada level sedang $(78,30 \%)$, dan 19 orang responden berada pada level tinggi (17,92\%). Oleh karena itulah dapat disimpulkan bahwa kemampuan pemahaman konsep matematis peserta didik sebagian besar responden berada pada level sedang.

Gambar 4 merupakan hasil interaksi antara tipe AQ dan kemampuan pemahaman konsep matematis.

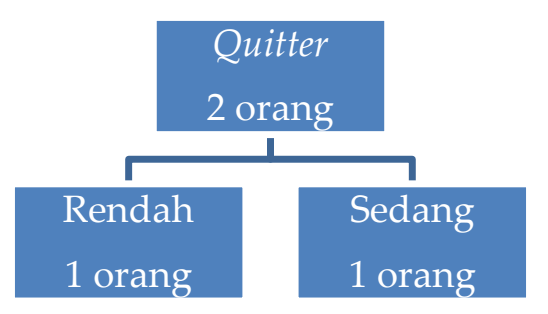

(a)

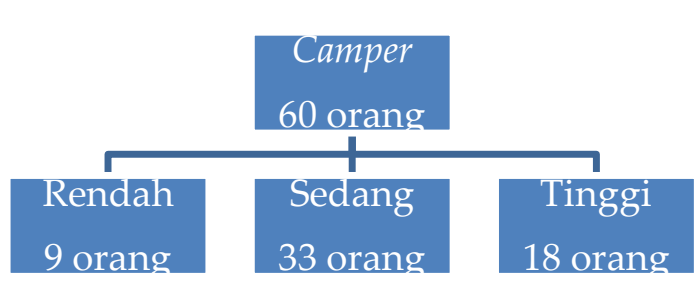

(b)

Copyright (C) 2020

Buana Matematika :

Jurnal Ilmiah Matematika dan Pendidikan Matematika 


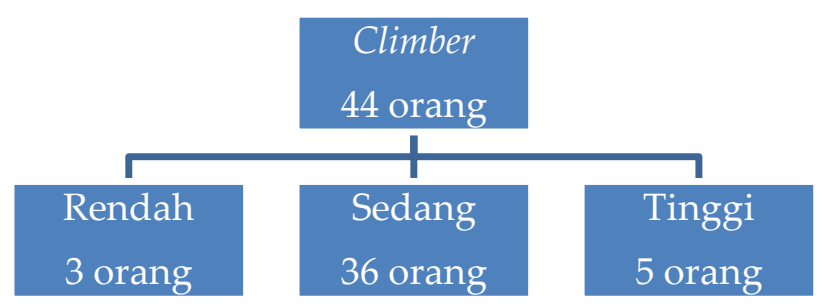

(c)

Gambar 4. Pemahaman konsep matematis berdasarkan tipe AQ (a) AQ quitter (b) AQ camper (c) AQ climber

Hasil tes kemampuan pemahaman konsep matematika kelas 11 MIPA disajikan pada tabel 2.

Tabel 2. Hasil tes kemampuan pemahaman konsep matematika

\begin{tabular}{cccc}
\hline NO & NILAI & BANYAK & KATEGORI \\
\hline 1 & $73-100$ & 23 & Tinggi \\
\hline 2 & $42-72$ & 70 & Sedang \\
\hline 3 & $0-71$ & 13 & Rendah \\
\hline
\end{tabular}

Dari tabel 2, diperoleh hasil tes kemampuan pemahaman konsep matematika peserta didik yang menunjukkan kategori tinggi 23 orang $(21,70 \%)$, kategori sedang 70 orang $(66,04 \%)$, dan kategori rendah 13 orang $(12,26 \%)$.

Sedangkan peserta didik yang bisa menjawab untuk masing - masing indikator kemampuan pemahaman konsep matematika disajikan dalam tabel 3.

Tabel 3. Banyaknya peserta didik yang menjawab tes setiap indikator

\begin{tabular}{|c|c|c|}
\hline No soal & Indikator Pemahaman Konsep & Jumlah peserta didik yang lulus \\
\hline $1(\mathrm{a})$ & Menyatakan ulang sebuah konsep & 9 \\
\hline $1(b)$ & $\begin{array}{l}\text { Mengklasifikasikan objek tertentu sesuai } \\
\text { dengan sifatnya }\end{array}$ & 2 \\
\hline & Memberikan contoh dan bukan contoh & 2 \\
\hline 2 & $\begin{array}{l}\text { Menyajikan konsep dalam berbagai } \\
\text { bentuk representasi matematika }\end{array}$ & 31 \\
\hline \multicolumn{3}{|c|}{$\begin{array}{l}\text { Copyright (C) } 2020 \\
\text { Buana Matematika : }\end{array}$} \\
\hline Jurnal & Ilmiah Matematika dan Pendidikan & $\begin{array}{l}\text { n Matematika } \\
\qquad \begin{array}{l}\text { p-ISSN : 2088-3021 } \\
\text { e-ISSN : 2598-8077 }\end{array}\end{array}$ \\
\hline
\end{tabular}


Vol. 10 No. 1 (2020)

\begin{tabular}{clc}
\hline No soal & \multicolumn{1}{c}{ Indikator Pemahaman Konsep } & Jumlah peserta didik yang lulus \\
\hline $3($ a) & $\begin{array}{l}\text { Menyajikan konsep dalam berbagai } \\
\text { bentuk representasi matematika }\end{array}$ & 0 \\
$3($ b) & $\begin{array}{l}\text { Menggunakan dan memanfaatkan } \\
\text { prosedur atau operasi tertentu } \\
4\end{array}$ & $\begin{array}{l}\text { Mengaplikasikan konsep atau algoritma } \\
\text { dalam pemecahan masalah } \\
5\end{array}$ \\
$\begin{array}{l}\text { Mengembangkan syarat perlu atau syarat } \\
\text { cukup dari suatu konsep }\end{array}$ & 81 \\
$\quad \begin{array}{l}\text { Mengembangkan syarat perlu atau syarat } \\
\text { cukup dari suatu konsep }\end{array}$ & 19 \\
& $\begin{array}{l}\text { Mengaplikasikan konsep atau algoritma } \\
\text { dalam pemecahan masalah }\end{array}$ & 19 \\
\hline
\end{tabular}

Dari tabel 3 terlihat bahwa indikator 4 pada soal nomor 3(a) dan indikator 6 pada soal 3(b) tidak ada satupun peserta didik yang menjawabnya. Adapun indikator 5 pada nomor 5 terlihat paling banyak dikerjakan oleh peserta didik. Selanjutnya pengkategorian $A Q$ berdasarkan skor $A Q$ yang di dapat peserta didik.

Tabel 4. Kategori AQ berdasarkan skor AQ peserta didik

\begin{tabular}{ccccc}
\hline NO & NILAI & BANYAK & KATEGORI & AQ \\
\cline { 1 - 4 } 1 & $166-200$ & 1 & TINGGI & \\
\cline { 1 - 4 } 2 & $135-165$ & 43 & CUKUP & \\
\cline { 1 - 4 } 3 & $95-134$ & 60 & SEDANG & CAMPER \\
\cline { 1 - 4 } 4 & $60-94$ & 2 & KURANG & \\
\cline { 1 - 5 } 5 & $0-59$ & 0 & RENDAH & QUITTER
\end{tabular}

Berdasarkan hasil skor AQ peserta didik, diketahui bahwa peserta didik paling banyak masuk ke dalam kategori sedang, kisaran skor 95 - 134 .

Berdasarkan uraian hasil penelitian, peneliti membagi hasil kemampuan pemahaman konsep matematika berdasarkan tiga tipe adversity quotient.

\section{Pemahaman Konsep Matematika dengan Tipe Quitter}

Berdasarkan hasil penelitian diatas, dapat diketahui bahwa terdapat 2 peserta didik yang memiliki tipe quitter.

Dilihat dari nilai yang didapatkan, termasuk dalam kategori rendah dan sedang. Peserta didik yang berinisial GF termasuk kategori rendah memperoleh jumlah skor yaitu 13 sehingga mendapatkan nilai 33. Sedangkan peserta didik yang berinisial AR termasuk kategori sedang memperoleh Copyright $\odot 2020$

\section{Buana Matematika :}

Jurnal Ilmiah Matematika dan Pendidikan Matematika 
jumlah skor 17 sehingga mendapatkan nilai 43. Berikut hasil peserta didik yang termasuk dalam tipe quitter terdapat pada gambar 5 dan gambar 6 .

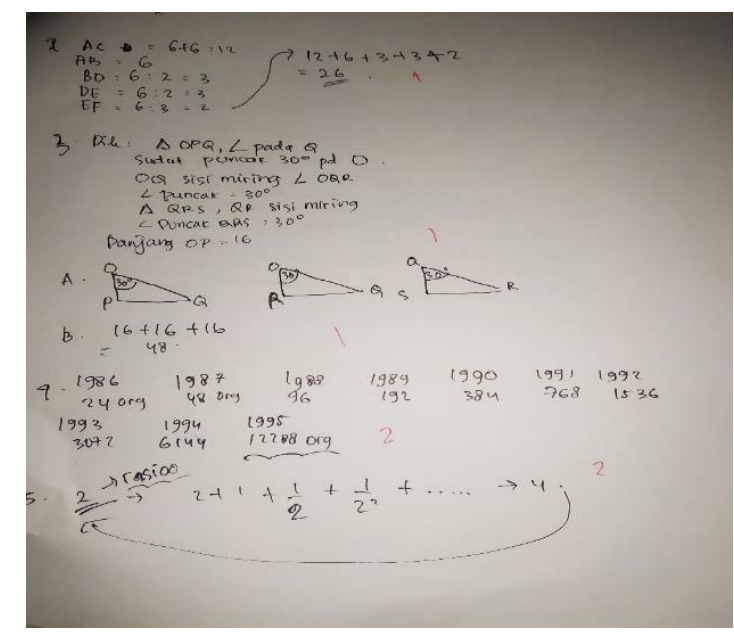

Gambar 5. Jawaban peserta didik dengan kategori rendah

Berdasarkan jawaban GF dalam mengerjakan tes, terdapat indikator pemahaman konsep yang tidak terpenuhi. GF tidak mampu menyatakan ulang sebuah konsep, memberikan contoh dan bukan contoh, serta tidak mampu mengklasifikasikan objek tertentu sesuai dengan sifatnya. Beberapa jawaban GF hanya sekedar menulis kembali apa yang dijelaskan di soal atau menyelesaikan tes secara manual.

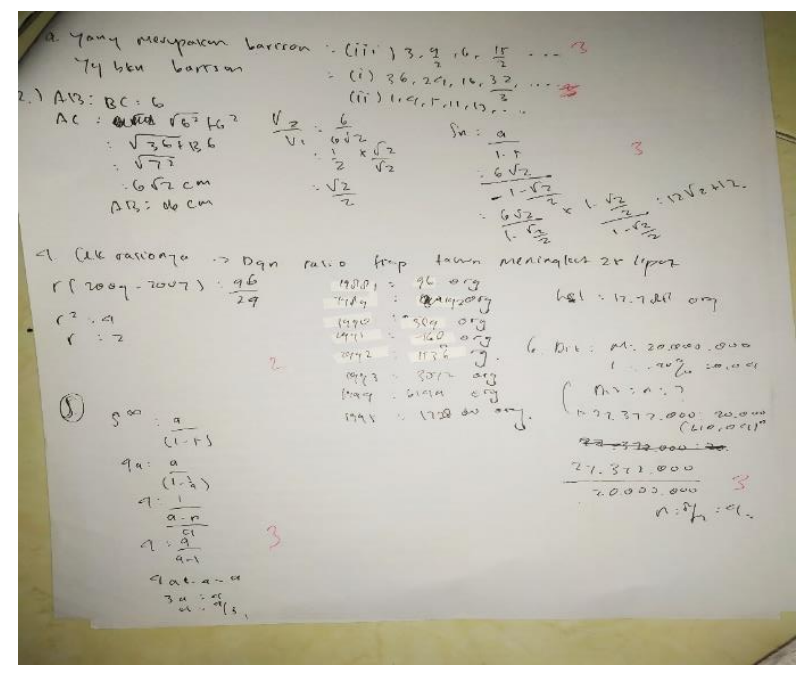

Gambar 6. Jawaban peserta didik dengan kategori sedang

Gambar 6 menunjukkan bahwa terdapat indikator pemahaman konsep yang tidak terpenuhi oleh AR, seperti mengklasifikasikan objek tertentu sesuai

Copyright (C) 2020

Buana Matematika :

Jurnal Ilmiah Matematika dan Pendidikan Matematika 
dengan sifatnya dan memberi contoh dan bukan contoh. Indikator yang lain hanya saja kurang tepat dalam menyelesaikan tes, disaat AR tidak memahami konsep nya, AR menyelesaikan tes tersebut dengan cara manual. Sehingga disimpulkan bahwa AQ tipe quitter cenderung mudah menyerah dalam menyelesaikan masalah. Sejalan dengan hasil wawancara Triwibowo et al., (2018) siswa berhenti mengerjakan atau melewati langkah ketika mengalami kesulitan.

\section{Pemahaman Konsep Matematika dengan Tipe Camper}

Berdasarkan hasil penelitian, dapat diketahui bahwa terdapat 60 peserta didik yang memiliki tipe camper. Peserta didik pada penelitian ini di dominasi oleh tipe camper.

Dilihat dari nilai yang di dapatkan, terdapat peserta didik yang memiliki nilai pemahaman konsep yang rendah hingga tinggi. Hal ini, membuat peneliti tertarik untuk menganalisis lebih dalam peserta didik yang memiliki nilai pemahaman konsep paling rendah dan tinggi.

Peserta didik yang termasuk kategori rendah berinisial AM memperoleh jumlah skor yaitu 6 sehingga mendapatkan nilai 15. Sedangkan peserta didik yang termasuk kategori tinggi berinisial DF memperoleh jumlah skor 32 sehingga mendapatkan nilai 80 . Berikut hasil peserta didik yang termasuk dalam tipe camper terdapat pada gambar 7 dan gambar 8 .

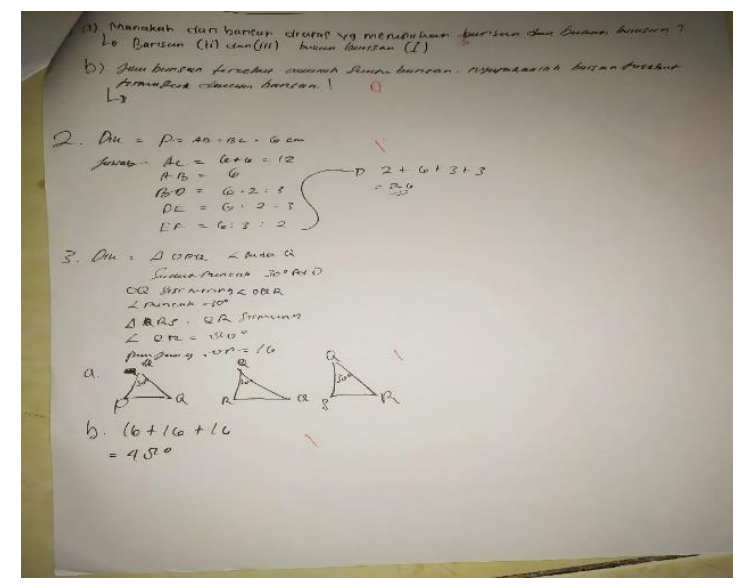

Gambar 7. Jawaban peserta didik dengan kategori rendah

Berdasarkan jawaban AM dalam mengerjakan tes, terdapat indikator pemahaman konsep yang tidak terpenuhi. AM tidak mampu memberikan contoh dan bukan contoh, serta tidak mampu mengklasifikasikan objek

Copyright (c) 2020

\section{Buana Matematika :}

Jurnal Ilmiah Matematika dan Pendidikan Matematika 
tertentu sesuai dengan sifatnya. Beberapa jawaban AM hanya sekedar menulis kembali apa yang dijelaskan di soal atau melihat jawaban teman sebangkunya.

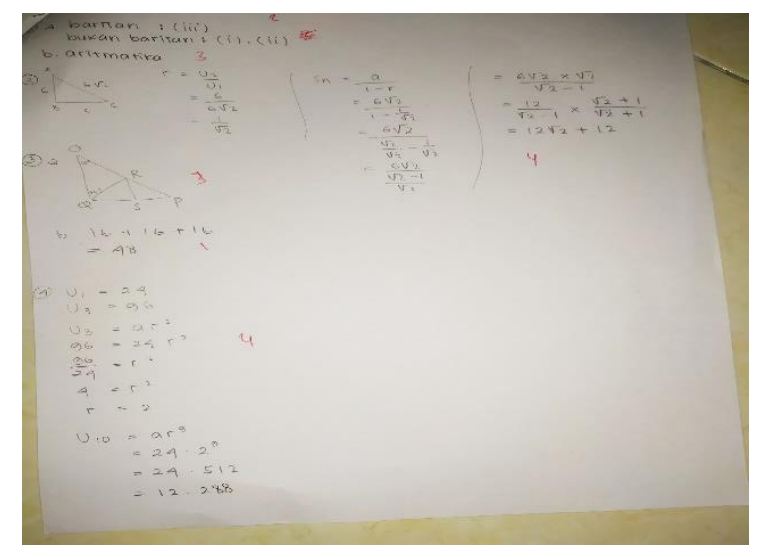

Gambar 8. Jawaban peserta didik dengan kategori tinggi

Gambar 8 menunjukkan bahwa DF mampu menyelesaikan masalah, mendapatkan beberapa nilai maksimal setiap indikator. Sama seperti peserta didik lainnya, mengalami kesulitan pada indikator menyajikan konsep dalam berbagai bentuk representasi matematika dan indikator menggunakan dan memanfaatkan prosedur atau operasi tertentu.

Hal ini dapat disimpulkan bahwa peserta didik yang memiliki tipe camper dapat menyelesaikan masalah dibanding tipe quitter, hanya saja menyelesaikannya masih mengandalkan ingatan atau hapalan Hidayat et al., (2018).

\section{Pemahaman Konsep Matematika dengan Tipe Climber}

Berdasarkan hasil penelitian, dapat diketahui bahwa terdapat 44 peserta didik yang memiliki tipe climber.

Dilihat dari nilai yang di dapatkan, terdapat peserta didik yang memiliki pemahaman konsep yang rendah hingga tinggi. Hal ini, membuat peneliti tertarik untuk menganalisis lebih dalam peserta didik yang memiliki nilai pemahaman konsep rendah dan tinggi.

Peserta didik yang termasuk kategori rendah memperoleh jumlah skor yaitu 18 sehingga mendapatkan nilai 45 . Sedangkan peserta didik yang termasuk kategori tinggi memperoleh jumlah skor 32 sehingga mendapatkan nilai 80 .

Copyright $@ 2020$

Buana Matematika:

Jurnal Ilmiah Matematika dan Pendidikan Matematika 
Berikut hasil peserta didik yang termasuk dalam tipe climber terdapat pada gambar 9 dan gambar 10 .

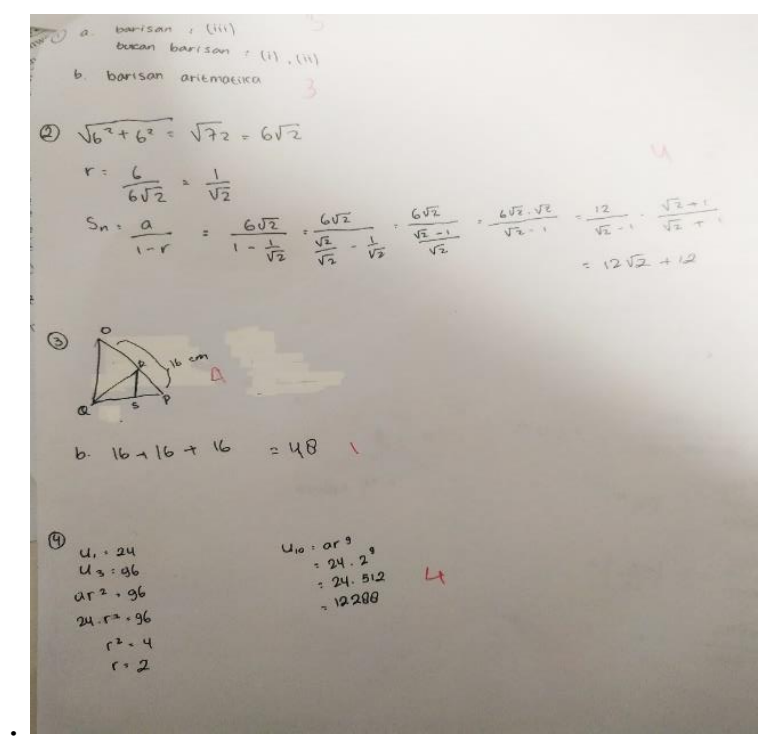

Gambar 9. Jawaban peserta didik dengan kategori tinggi

Berdasarkan jawaban SA dalam mengerjakan tes, terdapat indikator pemahaman konsep yang tidak terpenuhi. SA tidak mampu dalam menggunakan dan memanfaatkan prosedur atau operasi tertentu. Terlihat dari jawaban SA pada nomor 3(b) dikerjakan dengan cara manual.

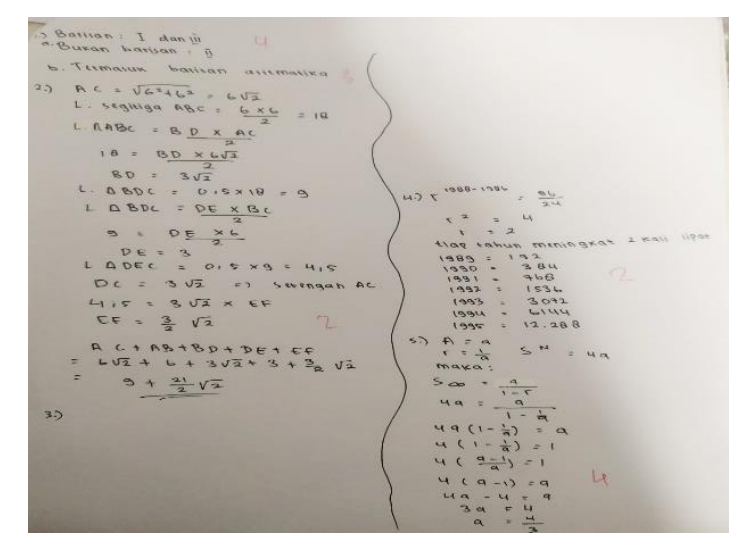

Gambar 10. Jawaban peserta didik dengan kategori rendah

Gambar 10 menunjukkan bahwa terdapat indikator pemahaman konsep yang tidak terpenuhi oleh NZ, diantara beberapa peserta didik lainnya NZ mampu meyelesaikan soal dengan indikator mengulang sebuah konsep. Namun, kendala yang sama dengan peserta didik lainnya yaitu peserta didik tidak mampu memenuhi indikator menyajikan konsep dalam berbagai bentuk Copyright (c) 2020

\section{Buana Matematika :}

Jurnal Ilmiah Matematika dan Pendidikan Matematika 
representasi matematika dan indikator menggunakan dan memanfaatkan prosedur atau operasi tertentu menggunakan dan memanfaatkan prosedur atau operasi tertentu. Sehingga disimpulkan bahwa AQ tipe climber lebih baik dibandingkan tipe AQ lainnya.

Berdasarkan hasil penelitian dan analisis jawaban peserta didik, dapat dimengerti bahwa kemampuan pemahaman konsep matematis peserta didik didominasi kategori sedang sebanyak 70 peserta didik atau 66,04\% dari keseluruhan. Adapun penelitian ini sejalan dengan penelitian Ningsih (2016) dimana penelitian menunjukkan hasil pemahaman konsep matematis mahasiswa tergolong cukup. Peserta didik mengalami kesulitan yang sama dengan mahasiswa pada indikator menyajikan konsep dalam berbagai bentuk representasi matematika. Kesalahan yang didominasi tidak mampu menggambarkan apa yang telah dijelaskan di soal. Selain itu indikator menggunakan dan memanfaatkan prosedur atau operasi tertentu termasuk kesulitan peserta didik dalam meyelesaikan masalah matematika. Tidak ada satu pun peserta didik yang mampu memenuhi kedua indikator tersebut. Lain hal nya dengan indikator mengembangkan syarat perlu atau syarat cukup dari suatu konsep, terdapat 81 peserta didik dari 106 peserta didik yang mampu memenuhi indikator. Peserta didik mengalami kesulitan dikarenakan kurangnya pemahaman konsep matematis sehingga peserta didik mudah menyerah ketika mengerjakan matematika sehingga peserta didik menyelesaikan masalah matematika dengan cara manual atau hanya mengandalkan hapalan.

Berdasarkan tabel 2 dapat diketahui bahwa terdapat 70 peserta didik yang memiliki kemampuan pemahaman konsep matematis kategori sedang. Hal ini sejalan dengan penelitian Budiarti et al., (2019) yang menyatakan bahwa model M - APOS memberikan pengaruh terhadap kemampuan pemahaman konsep tergolong sedang. Adapun indikator yang tidak mampu dipenuhi oleh peserta didik berdasarkan tabel 3 yaitu indikator menyajikan konsep dalam berbagai bentuk representasi matematika yang terdapat pada soal nomor 3(a), sesuai dengan hasil penelitian Ningsih (2016) yang menyatakan bahwa nilai mahasiswa untuk indikator menyajikan konsep dalam berbagai bentuk representasi matematika termasuk kategori sangat kurang. Hal ini dikarenakan peserta didik maupun mahasiswa tidak mampu dalam menggambarkan grafik maupun gambar dengan tepat. Selain itu, peserta didik tidak mampu dalam indikator menggunakan dan memanfaatkan prosedur atau operasi tertentu baik pada soal 3(b). Karena peserta didik tidak 
mampu menyelesaikan soal nomor 3(a) maka peserta didik tidak mampu juga dalam menyelesaikan soal nomor 3(b).

\section{Simpulan}

Berdasarkan hasil analisis data, dapat disimpulkan kemampuan pemahaman konsep matematis peserta didik kelas XI IPA SMAN 64 Jakarta yaitu tergolong sedang. Terdapat 23 orang (21,70\%) kategori tinggi, 70 orang $(66,04 \%)$ kategori sedang, dan 13 orang (12,26\%) kategori rendah. Dari hasil penelitian peserta didik mengalami kesulitan yang sama dalam menyelesaikan soal nomor 3(a) dengan indikator menyajikan konsep dalam berbagai bentuk representasi matematika dan soal 3(b) dengan indikator menggunakan dan memanfaatkan prosedur atau operasi tertentu. Namun dalam indikator mengembangkan syarat perlu atau syarat cukup dari suatu konsep pada soal nomor 5, peserta didik dominan mampu dalam menyelesaikan masalah matematika. Adapun tipe AQ yang dimiliki peserta didik cenderung pada tingkat sedang atau camper.

\section{Daftar Pustaka}

Budiarti, C. D., Purwanto, S. E., \& Hendriana, B. (2019). KONTRIBUSI MODEL PEMBELAJARAN M-APOS TERHADAP KEMAMPUAN PEMAHAMAN KONSEP MATEMATIS SISWA. KALAMATIKA Jurnal Pendidikan Matematika, 4(1), 15-22.

Fajar, A. P., Kodirun, Suhar, \& Arapu, L. (2018). Analisis Kemampuan Pemahaman Konsep Matematis Siswa Kelas VIII SMP Negeri 17 Kendari. Jurnal Pendidikan Matematika, 9(2), 229-239.

Gusniwati, M. (2015). PENGARUH KECERDASAN EMOSIONAL DAN MINAT BELAJAR TERHADAP PENGUASAAN KONSEP MATEMATIKA SISWA SMAN DI KECAMATAN KEBON JERUK. Jurnal Formatif, 5(1), 26-41.

Hidayat, W., Herdiman, I., Aripin, U., Yuliani, A., \& Maya, R. (2018). Adversity Quotient (AQ) dan Penalaran Kreatif Matematis Mahasiswa Calon Guru. Jurnal Elemen, 4(2), 230-242. https://doi.org/10.29408/jel.v4i2.701

Indriani, R., Puspita, A. M. I., Ninawati, M., Handayani, H., \& Agusfianuddin. (2019). CONTEXTUAL TEACHING AND LEARNING UNTUK MENINGKATKAN KEMAMPUAN PEMAHAMAN KONSEP PECAHAN. KALAMATIKA Jurnal Pendidikan Matematika, 4(1), 109-116.

Maharani, L., Hartono, Y., \& Hiltrimartin, C. (2013). KEMAMPUAN PEMAHAMAN KONSEP SISWA PADA PEMBELAJARAN MATEMATIKA

Copyright (C) 2020

Buana Matematika:

Jurnal Ilmiah Matematika dan Pendidikan Matematika 
MENGGUNAKAN MODEL GENERATIVE LEARNING DI KELAS VIII SMP NEGERI 6 PALEMBANG. JURNAL PENDIDIKAN MATEMATIKA, 7(2), $1-17$.

Mawaddah, S., \& Maryanti, R. (2016). Kemampuan Pemahaman Konsep Matematis Siswa SMP Dalam Pembelajaran Menggunakan Model Penemuan Terbimbing (Discovery Learning). EDU-MAT Jurnal Pendidikan Matematika, 4(1), 76-85.

Mulyono, B., \& Hapizah. (2018). Pemahaman konsep dalam pembelajaran matematika. KALAMATIKA Jurnal Pendidikan Matematika, 3(2), 103-122.

Ningsih, Y. L. (2016). KEMAMPUAN PEMAHAMAN KONSEP MATEMATIKA MAHASISWA MELALUI PENERAPAN LEMBAR AKTIVITAS MAHASISWA (LAM) BERBASIS TEORI APOS PADA MATERI TURUNAN. Edumatica, 06(1), 1-8.

Phoolka, S., \& Kaur, N. (2012). Adversity Quotient: A new paradigm in Management to explore. TIJ's Research Journal of Social Science \& Management - RJSSM, 2(7), 109-117.

Pranata, E. (2016). Implementasi Model Pembelajaran Group Investigation ( GI ) Berbantuan Alat Peraga Untuk Meningkatkan Kemampuan Pemahaman Konsep Matematika. 34-38.

Rahmawati, N. K., \& Kusuma, A. P. (2019). Hubungan Pemahaman Konsep Aritmatika Sosial Dengan Hasil Belajar Ips Materi Pph. Buana Matematika: Jurnal Ilmiah Matematika Dan Pendidikan Matematika, 9(1:), 1-6. https://doi.org/10.36456/buanamatematika.v9i1:.1976

Saputri, L. E., \& Sujadi, A. A. (2014). Upaya Meningkatkan Keaktifan Dan Pemahaman Konsep Matematika Siswa Melalui Creative Problem Solving Siswa Kelas Xi-Ipa1 SMA Negeri I Imogiri. UNION: Jurnal IPendidikan Matematika, 2(2), 183-190.

Stoltz, P., \& (Penerjemah), T. H. (2018). Adversity Quotient Mengubah Hambatan Menjadi Peluang (Y. Hardiwati, ed.). Jakarta: PT Grasindo.

Suraji, Maimunah, \& Saragih, S. (2018). Analisis Kemampuan Pemahaman Konsep Matematis dan Kemampuan Pemecahan Masalah Matematis Siswa SMP pada Materi Sistem Persamaan Linear Dua Variabel ( SPLDV ). Suska Journal of Mathematics Education, 4(1), 9-16. https://doi.org/10.24014/sjme.v3i2.3897

Triwibowo, Pujiastuti, E., \& Suparsih, H. (2018). MENINGKATKAN KEMAMPUAN PEMAHAMAN KONSEP MATEMATIS DAN DAYA JUANG SISWA MELALUI STRATEGI TRAJECTORY LEARNING. Prisma, Prosiding Seminar Nasional Matematika, 1, 347-353. Semarang: PRISMA, PROSIDING SEMINAR NASIONAL MATEMATIKA.

Copyright $@ 2020$

Buana Matematika :

Jurnal Ilmiah Matematika dan Pendidikan Matematika 
Yanti, A. P., \& Syazali, M. (2016). Analisis Proses Berpikir Siswa dalam Memecahkan Masalah Matematika Berdasarkan Langkah-Langkah Bransford dan Stein Ditinjau dari Adversity Quotient. Al-Jabar: Jurnal Pendidikan Matematika, 7(1), 63-74. 